\title{
Employee Skills, a Very Important Factor in Tourism Grouth
}

\author{
Zaim Korsi \\ PHD (candidate) UET \\ Lektor i lëndes Kontabiliteti i Ndërmarjes \\ Fakulteti i Biznesit, Universiteti“Aleksandër Moisiu", Durrës, Albania \\ Mob. +355692032107, e-mail; diamand96@yahoo.com \\ Dashurie Zeneli Hasani \\ Msc (candidate), Fakulteti i Biznesit, \\ Universiteti"Aleksandër Moisiu”, Durrës, Albania \\ Mob.+355696447830, e-mail; dashe_zeneli@yahoo.com \\ Arzena Korsi \\ Msc (candidate), Fakulteti i Biznesit, \\ Universiteti"Aleksandër Moisiu", Durrës, Albania \\ Mob.+355696022821, e-mail; arzena86@yahoo.com
}

Doi:10.5901/ajis.2014.v3n2p397

\begin{abstract}
We all face every day with the movement of a new era, and the era of knowledge economy. Employees need continuously for high level of education, acquisition of different and new behaviors, which helps to adapt to the changes of social environment which constitutes a challenges for development of tourism. The grouth of enhancement in the work environment affects positively in the development of a tourist economy. They form the basis of knowledge that are required to do the job, for the agreement between customers and managers and to increase the quality in tourism services that offers this sector. Job skills are not equal to the skills of the labor environment of the tourist sector. As Bob Nelson (2001) says "Never say that we don't need learning. New day is born and something new for us to continue the flow absent. "Reading, writing, math are the base of skill increase. Talking, speaking, listening, suitability are the basis of good communication and these help for problems solving, thinking creatively, effective work group which increases quality work group and interpersonal skills or influenced skills, for example the leadership and understanding the dynamics of a group. These are some items that makes tourism more attractive. We can never say that we know everything, because the development of technology is moving toward new technology and innovations. Years ago these skills are defined by being divided in 3 categories: basic skills, personal menagement and teamwork skillsevery day we got comments from employees about their salary and their dissatisfation is clear. it brings non eficance to employees who work in a turism sector. They are worry becouse for the same job they salary is in a same level like the other non qualified employees have. This comes from incompetence of leaders to identify their skills. All these things make up a complex type, that makes you feel "less than. . .". In the end we create several problems that tourism is facing nowadays. No matter how much power, brilliance or energy you have, if you dont use it and dont focus on a specific target you wont reach your goals Ziglar, 1985, p. 25).
\end{abstract}

Keywords: Employee skills, the tourist sector, social environment.

\section{Development}

Skills, commitment and professional behavior are criteria governing personnel to individual success and organizational growth, says Director of Pro Credit Bank (Hoxha, 2008) as a consequence, we have a service to perform well.

Basic skills are those skills primarily associated with academic skills such as reading and writing, mathematics, listening, and speaking. Comprehension skills that fall in this group are related to making questions and receiving information on a particular topic, including charts, diagram and tables, as well as spoken words etc. Thinking skills and problem solving are part of basic skills. These skills allow a person to analyze a situation, identify the core problem of the 
issue and resolve it. Also, the use of work technology to share knowledge accumulated over years is in itself the capability in which slowly is entering into this category.

"The key of success is having the right employees, in the right place" (Dell, 1988) Employees are not satisfied only by carring out the work and their responsibility does not end at this point. There are other elements that can motivate employees as: Responsibility-workers like to have a little freedom audits and decision in order to fill that they are an important part of the business.

The reward of good work-is when are practiced awards "The best employee of the month" etc. A valuation certificate is a good way that satisfies the employees. Promotion and growth- employee has always a natural desire to improve in his job over time and increase to higher positions. Flexibility-worker is not obliged to follow the set schedule, no worries and not pushed from superior in emergency situations. The supervisor gives the employee the right to choose the days of the week that he wants to work.

Personal management skills are related to behavior, and good skill helps, also, for self development. Increase of skills help a person to learn and advance positively in an organization. Personal management skills allow employees to balance work needs with those of personal life. Increase skills allow them to take responsibility, learn from their mistakes, accept feedback and be more open. Good social skills and ability to relate positively to other people do also fall into this category.

A person with good skills who is able to work in team is able to be successful working individually, too. Effective members of a team are able to learn best dynamics of a team. In addition, they understand very well the importance of being an active part of the team, best understand the purpose of the project, the nature of the work and objectives. The need of competition and success in business is forcing companies to pay good salaries to some employees who are the key to activity of the company in order to motivate them to do their best. "Motivation leads an individual to a curtain behavior and this is the reason why an individual displays different types of behavior. Thaves (1992) posted I am in search for motivation and I try to find a motivation while I go to work every day. "

They may choose to use different tools, to monitor project progress and to fit the aim through changes.

Bird (1990) says that a winner is someone who recognizes his God-given skills and uses these skills to accomplish his goals and to ensure further development of the organization.

"Knowledge" is the key of success for the economy presently. Organizations cannot raise expectations or flowering success without taking into consideration the serious gaps in the workforce, workers with a narrow set of skills, the impact of education and training of employees for the growth and success of the organization.

Presently the albanian business understands the need for a better training of employees. "Managers and companies should be aware how important is the role of the employees and their behavior for improving the results, achieving organizational objectives and business success. It is very important that every member of the team be satisfied in order to work willingfully. "(Hoxha, A. , 2008).

Knowledge and skills in the workforce are key to developing and maintaining a competitive advantage that will differentiate their company. Worldwide organizations and the ones operating in the Albanian market do not have the proper resources to compete economy of the twentieth century. That is because a large number of employees have lack of appropriate skills to give their best input on the growth and the prosperity of the organization. The global economy based on knowledge is giving special importance to the promotion of talent, creativity and efficiency of the workforce. Leaders and business executives expressed for an expansion of "the gap" between the skills of employees, for which organizations need to grow and the current skills of their employees.

"A gap in skill is a significant discrepancy between the organization's need for good skills in the workforce and actual skills that they have. This is where an organization can not grow or be competitive in its industry, because its workers have not the necessary skills to outcome oriented business and to support strategies and objectives of the organization". (Moncrief, 2004).

There are not only specific companies or industries, those who suffer the consequences of this deficiency in skill. From a study on Skills and Workforce Competencies of the Albanian labor

market, showed that the majority of firms ranging from large companies to small and medium enterprises. This study shows that these firms are facing a skills shortage to compete in the market, causing a gap between actual achievements and projected income businesses. The study suggests that this unrealized gains can be achieved through the development of new products and increased efficiency through technological improvements. However, all these choices are directed at one point: The required skills and more specifically, the study shows that there is a skills gap, which is evidenced between current capabilities of the firm's labor and the required skills to achieve and improve the performance of the company. In the beginning new things are not positive and is required a certain time to see their good 
side.

"If chaos after a change is due to poor implementation or abilities of people, we need to understand that there will for a curtain time a gap between where you are and where you want really to be. And, unfortunately, do not know how capable we are. "It is known as the valley of despair"

Maybe, you should feel worse before you feel better". By knowing this, you can skip the valley of despair, until things begin to change and your expected results begin to appear. Research have linked feelings of anxiety, stress, uncertainty to a decrease in self-respekt. This decline has a major impact on work and motivation.

You can see people's resistance as a problem and treat it urgently and so you will be sure that you will increase resistance. " Or you can see it as a signal that people need more information, or a better training (Moskowitz, 2011, p. 341).

There are raised much discussion on "how to equip with the right skills" through training and education, focused extensively on policy issues related to key education and training, the question arises: How to strengthen the education system in order to ensure a supply of labor with the right skills? Improving the education system is the key, so that the public and private sectors should cooperate in order to ensure that individuals who become part of the workforce, are equipped with the skills and the nessesery competencies in order to be more productive, grow and succeed.

The link between human capital and organizational success is even clearer today, given the fact that a deficiency in skills threaten the success and long-term success of businesses worldwide. In this practice, organizations always face some kinds of skills gap - if this does not happen, these organizations will not grow and to be taught in a step to changing market conditions and evolving industries changing customer needs.

The key to achieving business growth and sustainability is having the workforce with the capacity to learn constantly, update their skills and expand their knowledge in present environment that today is rapidly changing. " The key to achieving business growth and sustainability is having the workforce with the capacity to learn constantly update their skills and expand their knowledge in this environment of today's rapidly changing. "Employees want to be recognized for their individual performance through setting the position where they can give the maximum of their abilities "(Pfau \& Kay, 2001)

\section{Conclusions}

- Employee Skills are the key to success.

- Interconnection of individual performance with organizational performance is the basis for the well functioning of a business.

- Knowledge of employees and their skills helps in determining the proper working position.

- Motivating employees to make the best possible means that we are on the path to success.

\section{References}

Burns, K. (2010). Workplace expert, Workman Publishing Company.

Dell, T. ( 1988). An honest day 's work , Publisher: Crisp Learning.

Hoxha, A. ( 2008 ). How to motivate employees, Pro Credit Bank to Monitor newspaper.

Healthfield, S. (2000). Human Resources Guide, retrieved from www.humanresources.about.Com

Maskowitz, R. (2011). A Leadership Guide for Partnership in the Workplace, Publisher: Collier Macmillan.

Pfau, B. (2001 ). Human Capital edge, Edition Publisher: McGraw - Hill.

www. ziglar. com

www. dealbook. blogs. nytimes. com.

http://burime-njerezore. com/index. php?option=com

www. howtomotivateemployeesnow. com 